\title{
Genes e doenças genéticas
}

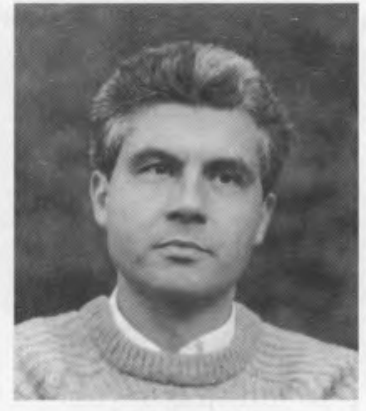

João Lavinha

Nasceu em 1949.

Assistente de investigação do Instituto Nacional de Saúde Dr. Ricardo Jorge. Completou em 1977 a licenciatura em química na Faculdade de Ciências de Lisboa e em 1983 o mestrado em ciências médicas na Faculdade de Medicina da Universidade de Glasgow. Após o seu regresso a Portugal (1983) iniciou a instalação, no âmbito do Laboratório de Genética Humana do Instituto Nacional de Saúde, do primeiro laboratório no País dedicado à biologia molecular das doenças genéticas humanas. Desde então tem desenvolvido um trabalho de interligação entre a investigação e o diagnóstico em hemoglobinopatias, hemofilias e fibrose quística.

\section{Os problemas}

Verifica-se que, quando a mortalidade infantil desce a níveis inferiores a 40 por mil (em Portugal ela é actualmente 12 por mil), as autoridades sanitárias nacionais começam a preocupar-se com as doenças genéticas em sentido lato o que inclui as anomalias cromossómicas, as doenças monogénicas e as doenças poligénicas e/ou multifactoriais. Isso é o resultado de a melhoria generalizada das condições de vida (alimentação adequada, habitação condigna e saneamento básico, escolaridade obrigatória) e a implementação dos cuidados de saúde primários (programas de vacinação em massa, terapêutica antibiótica), terem feito emergir o iceberg das doenças genéticas no meio do «mar» em regressão das doenças transmissíveis (regressão que está longe de ser irreversível a nível global, dado, p. ex., o enorme peso actual das doenças virais - hepatite B, SIDA, etc. - na morbilidade e na mortalidade humanas). De acordo com os dados publicados pela Organização Mundial da Saúde (1982), as anomalias cromossómicas e as doenças monogénicas ocorrem com uma frequência de 12 a 14 por mil nascimentos. Se a estas se juntarem as doenças multifactoriais e as malformações congénitas, verifica-se que o peso dos factores genéticos na patologia humana é da ordem dos 38 a 40 por mil nascimentos.

Face a esta situação, e na ausência de uma terapêutica eficaz, a estratégia mais adequada para o controlo das doenças genéticas parece ser a que combina o aconselhamento genético com o rastreio de portadores e o diagnóstico pré-natal (prevenção secundária). Paralelamente procura-se identificar no ambiente, nomeadamente dos locais de trabalho, os agentes (físicos ou químicos) potencialmente mutagénicos ou carcinogénicos, cuja remoção poderá contribuir para a prevenção primária das doenças genéticas. Alguns programas de prevenção secundária particularmente bem sucedidos foram levados a cabo na Bacia do Mediterrâneo (talassémia major), na comunidade dos judeus Ashkenazi dos EUA (deficiência em hexosaminidase A ou doença de Tay-Sachs) ou, ainda, na generalidade dos países do Norte (trisomia 21 ou sindroma de Down). P. ex., na Sardenha foi possível reduzir de $95 \%$ a incidência da talassémia major.

Por outro lado, o próprio conceito de doença de etiologia genética tem vindo a alargar-se às doenças crónico-degene-

\footnotetext{
a Laboratório de Genética Humana, Instituto Nacional de Saúde Dr. Ricardo
} Jorge, Av. P. Cruz, 1699 LISBOA CODEX 
rativas (aterosclerose, diabetes, etc.), às diferentes formas de câncro e, em sentido ainda mais geral, ao próprio processo fisiológico de envelhecimento ou aos chamados factores de susceptibilidade a patogénios. Assistiu-se, por isso, nas últimas duas décadas à «invasão» da genética em todos os campos da patologia humana e sua terapêutica (farmacogenética), o que obrigou a uma profunda alteração no ritmo e na qualidade das actividades de investigação e desenvolvimento nesta área.

\section{O objecto e os métodos}

Desde 1944 que sabemos, graças à experiência crucial de Avery, McLeod e McCarty em pneumococo, que a base material da informação genética é o DNA e não a proteína. Esta descoberta desencadeou um fortíssimo movimento científico e tecnológico no sentido de descrever e correlacionar a estrutura e a função do genoma de vários organismos vivos (das bactérias ao homem). A óbvia motivação de tais esforços tem sido a convicção (de tipo determinista e reducionista) de que, uma vez conhecido o «programa» genético (o genotipo) de um dado organismo, é possível deduzir e, eventualmente, manipular a sua expressão no correspondente fenotipo.

No caso do Homo sapiens, o objecto desta démarche - o genoma humano - é um conjunto de sequências polinucleotídicas (moléculas de DNA) com um comprimento total de $3 \times 10^{9}$ pares de bases. A título de comparação recorde-se que o genoma de uma bactéria (Ecoli) contém $2 \times 10^{6}$, um insecto (Drosophila) $10^{8} \mathrm{e}$ um anfíbio (Triturus) $2 \times 10^{10}$ pares de bases. O DNA, em conjunto com diversos tipos de proteínas, encontra-se organizado numa hierarquia de estruturas supra-moleculares de complexidade crescente: os nucleosomas, as fibrilhas de cromatina, os cromatídeos e os cromossomas. Apenas uma pequena parte $(\approx 10 \%)$ do genoma humano é codificante, estimando-se em S a $10 \times 10^{4}$ o número de genes estruturais (isto é que controlam a síntese de alguma proteína). Em termos de comprimento genético, medido pela frequência dos acontecimentos de recombinação em resultado de cross-overs entre cromossomas homólogos, o genoma humano mede 3000 centimorgans. Um centimorgan (cM) é a distância genética correspondente à frequência de $1 \%$ de recombinação o que, em média, equivale a $10^{6}$ pares de bases $(1 \mathrm{Mb})$. No entanto, não há uma ligação linear entre o comprimento físico de um cromossoma (em Mb) e o seu comprimento genético (em $\mathrm{cM})$. Diferente é também o comprimento genético de um mesmo cromossoma num homem e numa mulher (Figura 1) em resultado de uma diferente distribuição da frequência de recombinação ao longo do cromossoma nos dois sexos. Um cromossoma humano de dimensão média (grupo $\mathrm{C}$ que inclui os cromossomas 6 a 12 e o cromossoma X) contém entre 36 e $45 \mathrm{Mb}$. Durante a mitose, em metafase, os cromossomas condensam-se e podem ser identificados ao microscópio óptico: o comprimento, a posição do centrómero e, sobretudo, o padrão de bandas induzidas no processo preparativo, são as características distintivas. Os métodos convencionais da citogenética produzem cerca de mil bandas no conjunto dos cromossomas o que significa que cada banda terá, em média, $3 \mathrm{Mb}$. Os genes, as unidades estruturais e funcionais do genoma, têm dimensões muito variadas (de $10^{3}$ a $10^{6}$ pares de bases, Tabela 1) e organizam-se num número variável de segmentos codificantes transcritos e traduzidos (os exões), alternando com segmentos não codificantes transcritos mas não traduzidos (os intrões, que são excisados durante a maturação do RNA mensageiro, e as regiões de flanco que permanecem no mensageiro maduro). Foram também implicadas na regulação da expressão génica sequências de DNA mais remotamente localizadas: os promotores, os enhancers, os silenciadores e, mais recentemente, as chamadas regiões de controlo dominante (locus activating region, LAR ou dominant control region, DCR). Finalmente, a expressão génica é ainda influenciada por factores actuando em trans (proteínas reguladoras da transcrição cuja síntese é codificada por genes localizados noutros cromossomas).

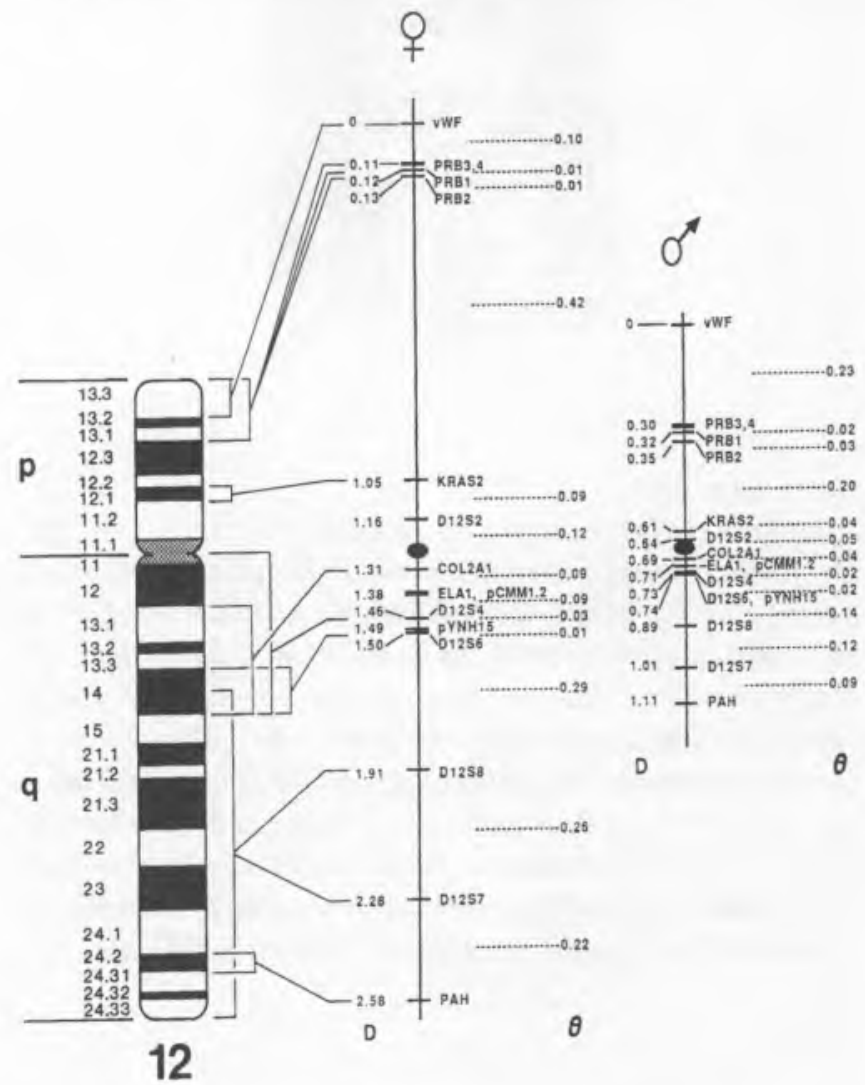

FIGURA 1

Mapas genéticos comparativos do cromossoma 12 do homem e da mulher À esquerda de cada diagrama as distâncias genéticas são acumuladas a partir do ponto zero e expressas em morgan $(D)$. À direita de cada diagrama os intervalos entre cada locus são expressos em fracçâo de recombinaçâo (8). Adaptado de Kaplan \& Delpech, 1989.

A elucidação de toda a complexidade do genoma humano implica a utilização de uma bateria de métodos com diferentes níveis de resolução e sensibilidade que constituem outras tantas «janelas» abertas sobre o objecto de estudo e através de cada uma das quais se podem observar apenas aspectos parciais do real (Figura 2). Este conjunto de métodos (classificáveis num de três grupos: análise de linkage, citogenética e biologia molecular) permitiu já identificar 2656 características como fazendo parte da herança mendeliana do homem e localizar 874 genes nos cromossomas humanos. Estes números representam apenas uma pequena parte do número total de genes da espécie o qual, como vimos, foi estimado em 5 a $10 \times 10^{4}$. 


\begin{tabular}{lcccc}
\hline $\begin{array}{l}\text { Gene } \\
\text { (tamanho } \\
\text { da cadeia } \\
\text { poplipe- } \\
\text { ptídica, kDa) }\end{array}$ & $\begin{array}{c}\text { Comprimento } \\
\text { do gene, kb }\end{array}$ & $\begin{array}{c}\text { Comprimento } \\
\text { do mRNA, kb }\end{array}$ & $\begin{array}{c}\text { Número } \\
\text { de exões }\end{array}$ & \begin{tabular}{c} 
Exões \\
\cline { 3 - 4 }
\end{tabular} \\
\hline $\begin{array}{l}\text { Interferão } \beta_{1} \\
(20 \mathrm{kDa})\end{array}$ & 0.9 & 0.9 & 1 & $100 \%$ \\
$\begin{array}{l}\beta \text { Globina } \\
(16.4 \mathrm{kDa})\end{array}$ & 1.6 & 0.623 & 3 & $39 \%$ \\
$\begin{array}{l}\text { Colagénio } \alpha \\
(165 \mathrm{kDa})\end{array}$ & 38 & 6.2 & 50 & $11 \%$ \\
$\begin{array}{l}\text { Apo-B } \\
(512 \mathrm{kDa})\end{array}$ & 43 & 14.1 & 29 & $31 \%$ \\
$\begin{array}{l}\text { Factor VIII:C } \\
(330 \mathrm{kDa})\end{array}$ & 186 & 9 & 26 & $5 \%$ \\
$\begin{array}{l}\text { Proteína FQ } \\
\text { CFTR } \\
(168 \mathrm{kDa})\end{array}$ & 250 & 6.5 & 24 & $3 \%$ \\
$\begin{array}{l}\text { Distrofina } \\
(427 \mathrm{kDa})\end{array}$ & $>2000$ & 14 & 60 & $0.7 \%$ \\
\hline
\end{tabular}

TABELA 1

Anatomia comparada de alguns genes humanos.

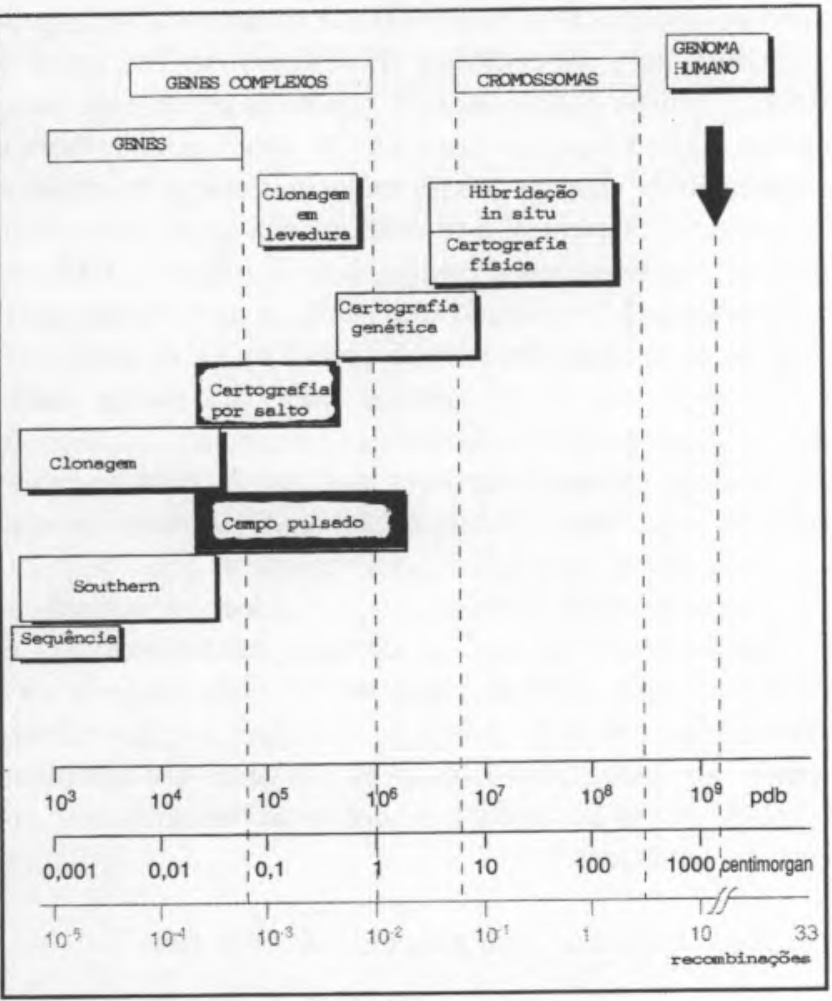

FIGURA 2

Poder de resolução dos diferentes métodos de exploração do genoma humano. Adaptado de Kaplan \& Delpech, 1989.

No caso específico da biologia molecular humana houve que usar (muitas vezes após adaptação) uma série de ferramentas antes desenvolvidas tendo em vista o estudo de outros sistemas biológicos. Primeiro trata-se de isolar as substâncias a analisar (DNA ou RNA) as quais são, em seguida, modificadas através da actividade catalítica de enzimas especializadas em cortar (nucleases e, em particular, endo- nucleases de restrição), copiar (DNA polimerases), transcrever (transcriptase reversa), religar extremidades coesivas ou abruptas (ligases), adicionar grupos fosfato (quinases), etc. Realiza-se, assim, uma espécie de bricolage molecular que, mimetizando a Natureza, produz os artefactos (DNA recombinante) ulteriormente usados como sondas na hibridação molecular ou na transformação de células procariotas e eucariotas para fins de investigação (estudos de expressão génica) ou tecnológicos (produção de proteínas heterólogas com interesse económico).

\section{Os resultados}

Ao fim de duas décadas de actividades de investigação e desenvolvimento na área da engenharia genética e medicina (Tabela 2), é oportuno fazer um balanço dos resultados obtidos.

1972 - Primeiro DNA recombinante in vitro.

1973 - Método geral de clonagem (de um gene de qualquer espécie biológica).

- I. Conferência sobre o Mapa Génico Humano (New Haven): 119 genes localizados.

1974 - Moratória preconizando a paragem das manipulações genéticas in vitro enquanto se preparava uma regulamentação.

II. Conferência sobre o Mapa Génico Humano (Rotterdam): 139 genes localizados.

1975 - Conferência Internacional sobre a Recombinação de DNA in vitro onde foi elaborado um projecto de regulamentação incluindo a noção de confinamento biológico.

- Método de Southern para a detecção de sequências de DNA específicas obtidas a partir de um genoma complexo por tratamento com endonucleases de restrição.

- III. Conferência sobre o Mapa Génico Humano (Baltimore): 167 genes localizados.

1976 - Primeiro diagnóstico pré-natal genotípico de $\alpha$ talassémia homozigótica por hibridação DNA/DNA em fase líquida com uma sonda não clonada.

- Descoberta do primeiro proto-oncogene (c-src).

- Primeiras clonagens de genes humanos: hormona lactogénia placentária, $\beta$ globina.

- Primeira localização cromossómica de um gene humano por hibridação molecular em fase líquida ( $\alpha$ globina no cromossoma 16).

- Descoberta dos intrões.

- IV. Conferência sobre o Mapa Génico Humano (Winnipeg): 185 genes localizados.

1978 - Primeiro polimorfismo de restrição humano (restriction fragment length polymorphism, RFLP) e sua aplicação ao diagnóstico pré-natal genotípico pelo método de Southern (drepanocitose).

- Primeiro banco de DNA genómico humano.

- Descoberta dà combinatória dos genes das imunoglobulinas que está na base da diversidade dos anticorpos.

1979 - Primeiros oligonucleotidos sintéticos usados como sondas moleculares.

- V. Conferência sobre o Mapa Génico Humano (Edinburgh): 235 genes localizados).

1980 - Primeiro RFLP humano detectado com uma sonda molecular anónima.

- Artigo de Botstein et al propondo uma estratégia geral para a cartografia genética do genoma humano usando RFLPs (genética reversa).

- Clonagem do genoma do virus da hepatite B (HBV) e descoberta da sua integração nos hepatocarcinomas.

1981 - Detecção do virus HBV no soro por hibridação molecular. - VI. Conferência sobre o Mapa Génico Humano (Oslo): 296 genes localizados. 
1982 - Primeira localização intracromossómica de um locus de doença desconhecido (distrofia muscular de Duchenne em Xp21) por linkage com um RFLP.

Descoberta do primeiro rearranjo génico num câncro (c-myc e genes das imunoglobulinas no linfoma de Burkitt).

Identificação da primeira mutação pontual num proto-oncogene (c-ras em câncro da bexiga)

Insulina humana recombinante.

Ratinhos transgénicos gigantes (micro-injecção do gene da hormona do crescimento recombinado por um promotor forte).

1983 - Primeira localização cromossómica de um locus de doença autossómica com defeito bioquímico desconhecido (coreia de Huntington no cromossoma 4).

Introdução, a partir do estudo do retinoblastoma, do conceito de mutação recessiva num gene supressor de tumores (anti-oncogene).

Sequenciação do genoma do virus da SIDA (HIV 1).

VII. Conferência sobre o Mapa Génico Humano (Los Angeles): 365 genes localizados.

1984 - Método de cartografia de grandes fragmentos de DNA $\left(10^{4}\right.$ a $10^{6}$ pares de bases) por electroforese em campo pulsado.

Clonagem e sequenciação do cDNA do factor anti-hemofílico VIII.

Clonagem dos genes do receptor de células T (TCR).

1985 - Descoberta de sondas mini-satélites (variable number tandem repeat, VNTR) e seu uso na obtenção de "impressões digitais" moleculares.

Primeiro diagnóstico pré-natal de uma doença de defeito bioquímico desconhecido, através do uso de RFLPs.

Localização dos loci de doença da fibrose quística (cromossoma 7) e da poliquistose renal dominante (cromossoma 16).

Método de amplificação selectiva de DNA in vitro (polymerase chain reaction, $\mathrm{PCR}$ ).

VIII. Conferência sobre o Mapa Génico Humano (Helsinki): 474 genes localizados).

1986 - Eritropoietina recombinante.

1987 - Clonagem e identificação do primeiro anti-oncogene (gene $\mathrm{RB} 1$ do retinoblastoma).

Macroclonagem em cromossomas artificiais de levedura (yeast artificial chromosomes, YAC).

Primeira vacina anti-HBV recombinante.

IX. Conferência sobre o Mapa Génico Humano (Paris): 601 genes localizados.

1988 - Reconstituição da sequência completa da distrofina (proteína produzida pelo gene responsável pela distrofia muscular de Duchenne).

1989 - Isolamento e identificação do gene da fibrose quística (CFTR). X. Conferência sobre o Mapa Génico Humano (New Haven): 827 genes localizados.

TABELA 2

Algumas datas importantes na história das aplicaçôes da engenharia genética à medicina.

\section{$A$ «Nova Genética»}

O que é a «nova genética»? Essencialmente é uma mudança na abordagem às doenças genéticas, deixando o ênfase de ser posto na análise ao nível clínico, celular e bioquímico para passar a sê-lo ao nível molecular. Passa a definir-se a doença genética em termos de patologia molecular. Com a análise directa e concreta do material genético a genética humana (e, portanto, a genética médica) ultrapassa o seu quadro abstracto tradicional. As hemoglobinopatias, pela sua frequência e a sua variedade, foram um terreno favorável ao desenvolvimento dos métodos e dos conceitos, permitindo ao mesmo tempo enriquecer os conhecimentos fundamentais (a organização dos genes, o seu agrupamento em famílias, os pseudogenes, ...) e diagnosticar os genes patológicos. A patologia molecular dos genes das globinas, ao revelar todas as varie- dades possíveis da anomalia (deleções ou mutações pontuais que afectam a transcrição, o processamento do RNA, a tradução, a regulação concertada da expressão de toda a família de genes, ...), forneceu um modelo para o estudo das alteraçōes genéticas susceptíveis de atingir os genes humanos. Â medida que mais genes reconhecidamente patológicos foram sendo clonados, os conceitos e os métodos desenvolvidos a propósito das hemoglobinopatias passaram a aplicarse ao conjunto das doenças genéticas. As que têm um modo de transmissão ligado ao cromossoma $\mathrm{X}$ beneficiaram não apenas do diagnóstico pré-natal mas também do diagnóstico de portadora, até então impossível de efectuar apenas com estudos fenotípicos. A clonagem de genes correspondentes a funções biológicas importantes permitiu observar a uma nova luz grandes áreas da fisiologia e da patologia humanas: genes das imunoglobulinas e sua combinatória geradora da diversidade dos anticorpos, genes dos interferões, dos factores de crescimento e oncogenes, dos receptores hormonais, das lipoproteínas, etc.

No que diz respeito às doenças genéticas de etiologia desconhecida, a estratégia da genética reversa (cujas bases teóricas haviam sido lançadas já em 1980) começou a produzir frutos em 1987 com o isolamento e a identificação de genes que codificam para proteínas até então desconhecidas: o gene RB1 (no cromossoma 13) para o retinoblastoma ou os genes DMD e BMD (no cromossoma $\mathrm{X}$ ) respectivamente para as distrofias musculares de Duchenne e Becker. Muitas outras doenças genéticas de etiologia desconhecida beneficiaram deste tipo de abordagem, embora a elucidação da respectiva base molecular esteja em estádios de evolução diferentes: a fibrose quística (cujo gene, cystic fibrosis transmembrane conductance regulator, CFTR, no cromossoma 7 foi isolado em 1989), a poliquistose renal dominante (cromossoma 16), a coreia de Huntington (cromossoma 4), etc. É de salientar que, para muitas destas doenças, é já possível o diagnóstico genotípico, incluindo o diagnóstico pré-natal, embora por um método indirecto (usando marcadores polimórficos do DNA estreitamente ligados ao locus patológico), uma vez que os genes respectivos ainda não foram isolados. Quanto às doenças poligénicas e multifactoriais (p. ex., as doenças cardiovasculares e, talvez, algumas doenças psiquiátricas) pode tentar-se uma abordagem através da utilização sistemática de marcadores ligados aos genes candidatos (p. ex., os genes que controlam o metabolismo dos lípidos ou dos neurotransmissores) em estudos familiares.

\section{O câncro resulta de uma patologia do DNA somático}

O primeiro oncogene celular a ser descoberto (1976) foi o proto-oncogene c-src parcialmente homólogo do oncogene retroviral $v$-src. Desde então demonstrou-se que várias dezenas de genes essenciais para a regulação fisiológica da multiplicação celular - os proto-oncogenes - podem concorrer para a proliferação tumoral quando sofrem alterações genómicas dominantes. A descoberta destes genes e dos seus mecanismos de activação constitui um dos progressos médicos mais importantes dos últimos anos, na medida em que abre uma via para a compreensão do processo de cancerização, sua prevenção e tratamento. Desde já comporta conse- 
quências imediatas nos planos do diagnóstico e do prognóstico das situações malignas. Para além destes genes em que os acontecimentos activadores são dominantes e somáticos, foi descoberta uma outra categoria de genes (de que o paradigma é o gene do retinoblastoma hereditário) - os genes supressores de tumores ou anti-oncogenes. As mutações de que são alvo são recessivas, sendo necessária a coincidência, numa mesma célula, de alterações afectando o mesmo gene em cada um dos dois cromossomas homólogos (homozigotia). Este modelo parece aplicar-se a um grande número de câncros (tumor de Wilms, câncros do colon, ...) nos quais foram encontrados loci lesados de maneira homozigótica. Também aqui existem implicações imediatas para o diagnóstico pré-natal e/ou pré-sintomático, bem como para o prognóstico.

Os genomas dos virus, das bactérias e dos parasitas são detectáveis por sondas moleculares específicas

A virologia, a bacteriologia e a parasitologia entraram já na era da biologia molecular pois a clonagem (total ou parcial) do genoma de alguns virus, bactérias e parasitas permite o seu estudo e diagnóstico e a preparação de vacinas. Por exemplo, a clonagem do virus da hepatite $\mathrm{B}(\mathrm{HBV})$ permitiu demonstrar a sua integração no DNA tumoral dos hepatocarcinomas (1980) e a produção de uma vacina recombinante, actualmente aplicada em larga escala. O virus da SIDA (human immunodeficiency virus, HIV), descoberto em 1983, foi já clonado e sequenciado, o que permite o estudo da sua biologia, o seu diagnóstico directo (p. ex., através da transcrição reversa do seu genoma seguida de amplificação enzimática selectiva por polymerase chain reaction, $\mathrm{PCR}$ ) e a concepção de diferentes estratégias para a produção de uma vacina.

\section{A engenharia genética fornece meios terapêuticos}

A produção industrial, em bio-reactores, de proteínas humanas com interesse terapêutico, graças à expressão de genes humanos inseridos em vectores apropriados e transferidos para um adequado sistema celular, pareceu, desde logo, um objectivo interessante. Este tem vindo a ser atingido com a produção da insulina, dos interferões, da hormona do crescimento, do factor estimulante de colónias de granulocitos e macrofagos (GM-CSF), da eritropoietina, do activador do plasminogénioe, em breve, também do factor anti-hemofílico VIII.

\section{A análise do genoma humano dá informação sobre a identi- dade e a genealogia dos indivíduos}

Hoje em dia, o emprego de sondas moleculares e a análise de um grande número de sequências do genoma humano vieram trazer uma base molecular à paleo-antropologia e à genética de populações. $\mathrm{O}$ uso de certas sondas hiperpolimórficas, os mini-satélites ou VNTR (variable number tandem repeats), permite caracterizar de forma praticamente absoluta o genoma de cada indivíduo sob a forma de uma «impressão digital» molecular, particularmente útil em medicina legal.

\section{A medicina preditiva na era da engenharia genética}

O diagnóstico pré-natal fenotípico e o estudo do sistema maior de histocompatibilidade (HLA) haviam aberto o caminho a uma medicina preditiva fundada na previsão ante-natal ou pré-sintomática. Na medida em que as alterações do genoma humano - mutações e micro-rearranjos cromossómicos passaram a ser directamente acessíveis à análise, o diagnóstico de um número crescente de doenças vai beneficiar desta abordagem. O diagnóstico pré-natal genotípico é já correntemente efectuado para as hemoglobinopatias (talassémias e drepanocitose), as hemofilias (A e B), a distrofia muscular de Duchenne e a fibrose quística.

\section{As perspectivas}

\section{A exploração sistemática do genoma humano}

Em sentido lato um projecto do genoma é um conjunto de actividades de investigação e desenvolvimento experimental visando a elaboração de mapas genéticos (ou de linkage) e de mapas físicos (ou de sequências de nucleotidos) de alguns cromossomas ou da totalidade do genoma. No entanto, as sequências de DNA só terão algum significado se exprimirem a riqueza do polimorfismo da espécie considerada e puderem ser correlacionadas com a respectiva função biológica. Os projectos do genoma humano poderão beneficiar a investigação (i) das doenças genéticas e das doenças transmissíveis (genética da susceptibilidade a patogénios); (ii) da fisiologia e do desenvolvimento (controlo da expressão genética); (iii) da base molecular da evolução; e (iv) da genética de populações.

Do ponto de vista das implicações éticas e sociais dos projectos do genoma, há que tentar equacionar um conjunto de questões preliminares, a saber:

* Como é que a variabilidade genética explica e justifica as diferenças (biológicas, sociais, comportamentais, ...) interindividuais? Em que medida os genes limitam (ou não) as opções dos seres humanos?

* Qual a relevância social dos resultados previsíveis de um projecto do genoma? Será possível compatibilizar as necessidades no campo da saúde com a oportunidade científica da investigação?

* Como se fará o controlo dos conhecimentos obtidos e do acesso à informação? A quem pertence a informação genéti$\mathrm{ca}$, ao indivíduo que a descobre ou à espécie humana no seu conjunto?

* Como resolver o conflito entre o discurso progressivamente mais reducionista das ciências médicas e a desejável prática da medicina o mais global e integrada possível?

Face ao surgimento, nos EUA, no Japão e na Europa, durante a década de 80 , de diversos projectos do genoma com objectivos parcialmente sobreponíveis, um grupo de trabalhadores científicos com particulares responsabilidades daquelas regiões do Mundo decidiu, em 1988, fundar a Human Genome Organization (HUGO) com as seguintes funções: (i) contribuir para a coordenação da investigação do genoma humano e proporcionar programas de formação nas metodologias relevantes; (ii) organizar o intercâmbio de dados, amostras e tecnologia utilizáveis na investigação do genoma; 
(iii) estimular estudos paralelos em modelos animais e coordenar essas investigações com o projecto do genoma humano; e (iv) promover o debate público e elaborar directrizes sobre as implicações éticas, sociais, legais e comerciais do projecto do genoma.

\section{A terapêutica génica}

As aplicações clínicas dos mapas genéticos e físicos do genoma humano, até agora praticamente limitadas ao diagnóstico, podem vir a incluir a inserção de DNA normal directamente em células somáticas, tendo em vista a correcção de um dado defeito genético. $\mathrm{O}$ avanço da terapêutica génica dependerá do desenvolvimento de processos inócuos e eficientes de inserção do DNA estranho nas células-alvo e de esse DNA, uma vez integrado no genoma receptor, corrigir de facto o defeito genético, o que implica que o gene normal «enxertado» se exprima no momento, no local e ao nível fisiológicos. Os primeiros candidatos a uma acção terapêutica deste tipo serão provavelmente os genes da hipoxantina-guanina fosforribosiltransferase (HPRT) cuja deficiência provoca a doença (neurológica) de Lesh-Nyhan e da adenosina desaminase (ADA) cuja deficiência está implicada na imunodeficiência combinada grave.

\section{$A$ "perfeição» humana (desenvolvimento e evolução)}

Existe uma profunda e extensa lacuna entre o conhecimento a nível molecular (DNA $\Rightarrow$ RNA $\Rightarrow$ proteína) e o conhecimento do que se passa a nível fisiológico (fenotipo) como resultante de uma interacção dinâmica entre o genotipo e as diferentes componentes do ambiente (incluindo o próprio background genético do indivíduo): de facto, o mesmo gene, em diferentes ambientes, produz diferentes fenotipos, enquanto, pelo contrário, genes diferentes, em diferentes ambientes, podem produzir o mesmo fenotipo (a fenilcetonúria clássica causada pela deficiência de fenilalanina hidroxilase ilustra bem estas situações). Por outro lado, não se pode ignorar o papel activo desempenhado pelos organismos vivos na transformação do seu próprio ambiente. Eles não são sistemas estritamente programados para responder mecanicamente aos desafios do ambiente. Em particular os seres humanos fazem a sua própria história, embora em circunstâncias que não escolheram. Esta é uma das razões pelas quais o conhecimento do passado evolutivo não permite predizer o curso do futuro evolutivo. A evolução humana não parou com o aparecimento do Homo sapiens sapiens: a evolução biológica continua como uma propriedade intrínseca da matéria viva; a evolução sócio-cultural, por seu lado, é o produto da interacção de factores biológicos, económicos e culturais e das acções conscientes dos indivíduos. A compreensão dessa interacção escapa seguramente às metodologias da biologia. Não sabemos, nem podemos prever, os limites que o nosso genoma impõe à natureza humana. A única coisa que sabemos é que não há limites óbvios.

\section{Em Portugal}

O levantamento das informações sumarizadas a seguir está longe de ter sido sido exaustivo. Procurou-se apenas exem- plificar áreas científicas, instituições e localidades onde, no nosso País, se faz o estudo do genoma humano (ou de outros organismos com implicações na saúde humana ou que podem ser usados como modelo da fisiologia e/ou da patologia humanas) ao nível molecular.

\section{Áreas científicas}

Anatomia, biofísica, biologia celular, biologia molecular, bioquímica, bioquímica genética, biotecnologia, endocrinologia, enzimologia, genética, genética humana, hematologia, histologia e embriologia, imunologia, infecciologia, microbiologia, neurobiologia, oncobiologia, parasitologia, patologia, patologia morfológica, química física molecular e virologia.

\section{Instituições}

Centros de investigação:

Centro de Citologia Experimental (biofísica, biologia molecular, microbiologia e imunologia), Instituto de Genética Médica (enzimologia), Instituto Gulbenkian de Ciência (bioquímica, genética, virologia) e Instituto Nacional de Saúde (bioquímica genética, genética humana, hematologia, microbiologia experimental, paramiloidose, parasitologia, resistência aos antibióticos, virologia, zoonoses).

Hospitais centrais:

Hospital de S. António (imunologia), Instituto Português de Oncologia - Norte (imunologia) e Instituto Português de Oncologia - Sul (endocrinologia, patologia morfológica).

Universidades:

Departamento de Zoologia da Universidade de Coimbra (biologia celular), Escola Superior de Medicina Veterinária (doenças transmissíveis), Faculdade de Ciências Médicas de Lisboa (genética, imunologia), Faculdade de Ciências do Porto (antropologia), Faculdade de Ciências e Tecnologia - UNL (biotecnologia), Faculdade de Farmácia de Lisboa (microbiologia), Faculdade de Medicina de Coimbra (histocompatibilidade, imunologia), Faculdade de Medicina de Lisboa (histologia e embriologia, imunologia), Faculdade de Medicina do Porto (genética, hematologia, imunologia, patologia), Instituto de Ciências Biomédicas Abel Salazar (anatomia, imunologia) e Instituto Superior Técnico (química física molecular).

\section{Localidades}

Lisboa, Porto, Coimbra, Oeiras e Águas de Moura.

No que respeita à prevenção das doenças monogénicas na população, é já possível realizar entre nós - no Laboratório de Genética Humana do Instituto Nacional de Saúde - o diagnóstico pré-natal de hemoglobinopatias (drepanocitose e talassémias), de hemofilias (A e B) e de fibrose quística. 
Agradecimentos

Agradeço a Leonor Osório-Almeida e a Anabela Dias os pertinentes comentários que fizeram após uma leitura do manuscrito.

\section{Referências}

- Cold Spring Harbor Laboratory (1986) Molecular biology of Homo sapiens, Cold Spring Harbor Symposia on Quantitative Biology, Volume LI (Parts A and B).

- Jordan B (1989) Les cartes du génome humain. Recherche 20: 1486.
- Kaplan J-C \& Delpech M (1989) Biologie moléculaire et médecine, Paris, Flammarion.

- McKusick VA (1990) Mendelian inheritance in man: Catalogs of autosomal dominant, autosomal recessive and X-linked phenotypes, 9 th ed; Baltimore, Johns Hopkins Univ. Press.

- Rose S (1984) DNA in medicine: Human perfectibility. Lancet II: 1380.

- Rose S, Kamin LJ, Lewontin RC (1984) Not in our genes - Biology, ideology and human nature, Harmondsworth, Penguin.

- United States Congress, Office of Technology Assessment (1988) Mapping our genes - The genome projects: how big, how fast? OTA-BA-373, Washington DC, US Government Printing Office.

\section{A SPQ é sua amiga Você é amigo dos seus amigos Os seus amigos são amigos da SPQ?}

\section{BOLETIM DE INSCRIÇÃO SPQ}

Nome

\section{Morada}

Telefone

Delegação a que deseja pertencer: Coimbra

$\square$ Lisboa Porto Endereço Profissional

Habilitações Académicas

Cargo que desempenha Junto envio o cheque $\mathrm{n}^{\circ}$ do Banco

referente à minha quota da SPQ no ano de 1991 . de de 1991

Assinatura 


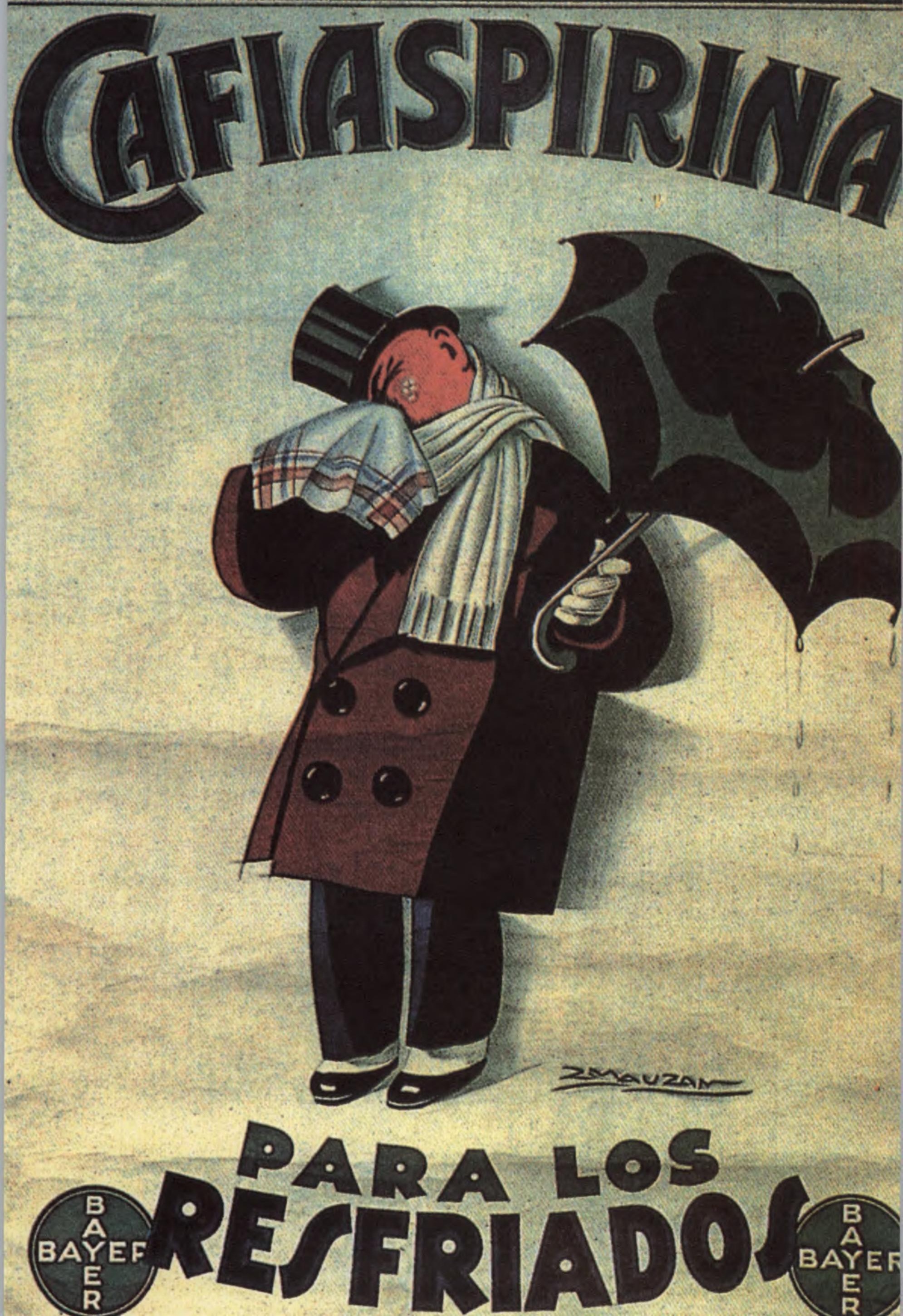

